\title{
POLICE PROCEDURE AS A POSSIBLE INDICATOR OF INSTITUTIONAL EXTREMISM
}

\author{
Mirjana Radetić - Paić, PhD \\ Department for the education of teachers and child-care teachers \\ University Juraj Dobrila in Pula \\ e-mail: mradeticpaic@ hotmail.com \\ Valter Opašić, univ.spec.oec., \\ Ministry of Internal Affairs of the Republic of Croatian \\ Head of Department of analytics reporting and public relations PU Istarske \\ e-mail: vopasic@gmail.com \\ Ivan Kostešić, student, \\ Department of Preschool and Primary Education \\ e-mail: ivankontesic@gmail.com
}

\begin{abstract}
Summary
A hypothesis was formulated that the Roma from the Istrian County, The Republic of Croatia, will estimate the police procedures toward them are different in certain aspects from the procedures toward the local people because of the fact that they are members of one of minority groups and that the facts stated can be indicators of institutional extremism.

The results indicate that there are differences in the evaluation of police procedure between the Roma and the remaining Istrian population.

The scientific and practical value of the results of this work provides the guidelines for the creation and implementation of the measures for the prevention of racism, intolerance and segregation, whereby a special role is played by the state bodies, primarily of the Istrian County and the local government.
\end{abstract}

Key words: institutional extremism, police procedure, the Roma

\section{Introduction}

Institutional extremism is a process including members of certain ethnic, religious or other groups systematically discriminated and disrespected by individuals working in these institutions. It is possible in this way for civil services and institutions to be bearers of racial, religious, sexual or any other discrimination, without that being recognized and acknowledged, despite of existing procedure policies aimed at ellimination of racial discrimination. This is a more non-critical, and less unconscious extremism. The practice which leads to extremistic outcomes 
is not something that happens without the knowledge of those who perform it. They just fail to take into consideration the consequences of their actions for the members of ethnic minorities.

Basically, extremistic violence includes criminal offences against life and entity, general safety of people and property and various other types of violent offences the victims of which are members of certain, usually minor social groups. It is, in fact, a question of extreme expression of prejudices and sterotypes which exist in a particular community. These stereotypes can be created on a racial, ethnic or religious basis (Cajner Mraović and Mraović, 2000). Extremism or extremistic delinquency is different from other offences because the committer's of the extremistic act main aim is to send a message to the members of certain, usually minor groups in a particular community, neighbourhood, school or working place. The most usual determinant of extremism is racial hatred, but also other types of extremism are known, e.g. ethnic, sexual, religious and, recently, sexual and discrimination of persons having special needs.

The main determinators of extremism, and at the same time of institutional extremism are, as already mentioned, prejudices and stereotypes. Such prejudices usually have their sources in the social environment which sees differences as a danger and threat. One way of expressing this prejudice is to create the perception that society imposes sanctions on differences. This perception is created by both violence and uncriticality, by neglecting or failing to deal with certain social groups which are to some extent different from the majority population of a territory.

The usual practice of fighting extremism when it comes to extremistic violence, i.e. the reaction of governmental services and institutions including the police and local governments has, in many countries, been put down to negation.

When it came to racist murders and violent attacks in Great Britain during the seventies of the 20th century, people in power there negated the possibility of the existance of any problem. Even when in 1981 the British government addmitted the existance of extremistic and racial violence in the country, it still negated the former existance of such a problem reffering to insufficient proofs which were mostly presented by different associations and minority members' organisations (Cajner Mraović and Mraović, 2000).

Analysing the victimisation of Afro-American women, and considering rape as an extreme violence for any woman, Ogawa (1988) sees differences in the legal system procedures in the largest sense towards them and other women. Schwendinger and Schwendinger (1983) gathered facts that, although laws about racism do not differ people according to the colour of their skin, it is disturbingly evident that Afro-American victims will not be given the same treatment by the legal system as other women will. In other words, there is a discordance between a high degree of victimization and a low degree of proper, valid approach for Afro American women and other women in the same area (Belknap, 1996).

Analysing the exceeding of authority by police officers, Janofsky (1997) states that in the United States of America it is widespread that police officers discriminate minorities, especially Afro-Americans, which has been confirmed in a number of incidents (brutal procedure, corruption and so on). 
Westly (2004) concludes that the police act in a certain way, i.e. exceed their authority, to gain respect especially with minority groups. Similarly, based on his researches' results, Franklin (2000) comes to the fact that in some local communities the committers of offences with extermistic characteristics consider their behaviour positive and believe thet the community approves the violence they perform over different minority groups.

According to the same author (Westley, 2004), police violence is a prerogative profession and a duty in some countries. The police have the power which includes violence because in a civil society they have the monopoly over the legal means of violence belonging to the state. It is the police's duty to use violence as a measure suitable to control or prevent a possible disruption of order which is especially revealed with minority groups. Capturing and sentencing offenders is the police's main duty. At the same time they are under constant public pressure and criticism and under the dilemma of capturing (with the problem of insufficient proof) and on the other side, public opinion which forces them to take things into their hands. The author says that the formerly mentioned dilemma is solved in the United States of America by illegal use of violence and exceeded use of authority.

Westley (2004) supplies us with the data that 37 percent of examinees from the observed sample (50 percent of them were from the police station) believe in the legitimacy of violence with the aim of imposing respect toward the police. It is also emphasized that a police officer will not impose sanctions on his or her colleagues which exceed their authority using vilence.

In this way collective sanctions because of violence permit to those who like using it to do it with no fear. It must not be forgotten, however, that every police officer is conscious of the danger linked to the illegal use of violence, so they use limited violence and they can always justify the exceeded use of authority with the accusation that a person did not want to collaborate.

Any citizen from any local community has the need and the right to be safe and protected and if they do not feel like that a lack of engagement will be noticed especially in collaboration with the police. This problem is emphasized with members of minority and other vulnerable groups, especially the Roma, which is often one of the main reasons of their not taking part into community initiatives.

Table 1: The number of Roma in the Republic of Croatia according to the census of 1948 to 2001.

\begin{tabular}{|l|c|c|c|c|c|c|c|}
\hline $\begin{array}{l}\text { THE YEAR OF } \\
\text { THE CENSUS }\end{array}$ & 1948 & 1953 & 1961 & 1971 & 1981 & 1991 & 2001 \\
\hline $\begin{array}{l}\text { THE NUMBER } \\
\text { OF ROMA }\end{array}$ & 405 & 1,261 & 313 & 1,257 & 3,858 & 6,695 & 9,463 \\
\hline
\end{tabular}

According to the census from 2001 in the Republic of Croatia there were 9,463 Roma (600 Roma in the County of Istria), but there are estimates that there are between 30,000 and 40,000 Roma living in it (The National programme for the Roma, 2003). 
The postsocialistic transition created new problems for the Roma with regard to services offered by some institutions. The Roma, as a minority, faced limitations of being given social services because of a general growth in demand and reduces to the budget. Earlier, in socialism, most of the services were free. Their use today needs a formal or informal payment, and inadequate service qualities can also be noticed. Fiscal problems of postsocialist countries had as a consequence a reduction in public means for building and maintenance of social appartments (Šućur, 2005). It indirectly became "fertile soil" for different kinds of institutional extremism.

Institutional extremism influences the rutine reaction and dealing with extremistic offences, but also the way in which the members of some, usually minor groups will be treated as workers, witnesses, victims, suspects and citizens.

The reaction of the society to the question of extremistic victimisation of an individual seriously influences the way in which the members of ethnic, ratial, religious ar any other groups which are the object of the violence think, feel and act in a social community. This influences their choice of a living place, working place and place for their free time and socialization. The members of such, usually minor groups are afraid of any forms of violence on their life or entity, and they are not satisfied with the protection given by the society. This is why they often organize themselves which is the base for new violence. Defence can easily turn into offence giving way to new extremistic groups and new threats to peace and democracy.

It can be concluded that minority groups members do not want to denounce extremistic offences which they are victimized by because of the fear that the legal system is not on their side. In this sense they very often show lack of confidence toward the police to which the offences are being denounced.

\section{Methodology the aim of the research, hypothesis}

This article is part of the research "The police and the protection of vulnerable groups: underaged, women and minorities" of the Zagreb Police Academy in the Republic of Croatia.

It is a research about the relationships between some groups of people which are particularly vulnerable according to the Reference book about the Human Rights and Humanitarian Law for the police and forces for safety of the International Red Cross Committee. The UN reference book on human rights says that these social groups need special protection and treatment.

Taking into consideration recent researches (Bowling, 1999; Ogawa, 1999; Levin, 2002) which show that the victims of extremistic offences need on avarage more time to recuperate from the attack and that they are less satisfied with the police treatment from other groups, a general aim has been set in this article to find out if there are differences in police procedures toward the Roma as a minority group in Istria and the local population. These aims want to estabilish the following:

- Are the Roma more exposed to negative experiences with the police than the local population; 
- Do the Roma estimate more than the local population that the police exceed their authority;

- Do the Roma think that they are less sufficiently informed by the police about the possibilities of filing complaints than the local population;

- Do the Roma think that they are less sufficiently informed by the police about the advice for protection from crime than the local population;

- Do the Roma consider the police insufficiently consistent in their procedures with the difference of the local population.

A hypothesis was formulated that the Roma will estimate the police procedures toward them are different in certain aspects from the procedures toward the local people because of the fact that they are members of one of minority groups and that the facts stated can be indicators of institutional extremism.

As in the Istrian County, Republic of Croatia, there are no comparative research results of the problem, the hypotheses were set as nul-hypothesis:

HO1: there are no differences in unpleasant experiences with the police between the Roma and the local population;

HO2: there are no differences in estimations with the Roma and local population about the frequency of the police exceeding their authority;

HO3: there are no differences in estimations between the Roma and local population about the sufficiency of the police informing the public about the possibilities of filing complaints;

HO4: there are no differences in estimations Between the Roma and local population about the sufficiency of the police giving advice to the public about protection against crime;

HO5: there are no differences in estimations between the Roma and the local population about the consistency of police officers.

\section{Examinees sample}

Two samples have been formed: 200 examinees of the Roma minority group from the Istrian County, The Republic of Croatia, and 200 examinees from the local population of the same area.

The samples are occasional. The sample of the Roma exminees has been chosen from the evidences of six Social Care Centres from the Istrian County, the Republic of Croatia, since it was supposed that these Centres still had the most complete data about the members of the examined national minority, and that a large number of their members used their social rights (to $3 / 4$ of households social help is the first or second source of income) and some recent researches show that (Šućur, 2005). The local population has been ecqualized according to gender, age and education with the examined group of the Roma, and it mostly chosen from the evidences of the same centres since it was similar to the Roma group not just according to these generalities but also according to socio-economic circumstances (having some kind of material care). A smaller part of these examinees has been 
chosen from the Central Employment Office. The samples of the Roma and local population are therefore not representative for the Roma and local population of Istria, the Republic of Croatia, as a whole.

\section{Variable sample}

The questionnaire has been made in cooperation with the Study group for planning, implementation and monitoring of the "Police in the community" Strategy, the Study group for planning, implementation and monitoring of the project Organization of municipal prevention and the OESS mission in Croatia. The questionnaire has been divided into three larger groups of variables. In this research the group of variables concerning the personal estimation of police procedure in the area of living, and the group of variables concerning personal experiences with the police has been used. All the questionnaires in this research are annonymous and solely used for scientific research.

\section{Methodology of data processing}

The $x^{2}$ test has been used in data processing, along with the working out of absolute and relative frequentions.

\section{Discussion and results}

Looking at Table 2 it is evident that the Roma had more unpleasant experiences with the police than the local population. The Roma estimate that they did not have an unpleasant experience in 26.5 percent of cases, while the other population says that they did not have such an experience in 44.5 percent of cases.

Twenty-five percent of the Roma had an unpleasant experience with the police which is more than the local population (16.5 percent). A member of the Roma family ( 21.5 percent) had an unpleasant experience with the police with the difference of the local population where in just eight percent of cases the same thing happened. Based on indicators about unpleasant experiences with the police it can be concluded that the local population and the members of their families had less personal unpleasant experiences with the police or that they knew more people with such an experience ( 31 percent) than the Roma (27 percent).

By doing the $x^{2}$ test the value 25.516 is obtained. With the third degree of freedom on the level of importance of 0.05 the marginal value of the test is 7.815 so these indicators can be considered as significant, not accidental.

Taking into consideration all the positive estimates in Table 3 , in the sense that the police frequently exceed their authority, there are 60 percent of such cases presented between the Roma, and just 40 percent between the local population.

The $x^{2}$ test gives the value of 13.570. With the third degree of freedom on the level of importance of 0.05 the marginal value of the test is 7.815 , so these indicators can be considered as relevant, not accidental. 
Table 2. Unpleasant experience with the police

\begin{tabular}{|c|c|c|c|c|c|c|c|c|c|}
\hline \multicolumn{10}{|c|}{ Absolute and relative frequencies } \\
\hline & & \multicolumn{2}{|c|}{ All } & \multicolumn{3}{|c|}{ THE ROMA } & \multicolumn{3}{|c|}{$\begin{array}{c}\text { OTHER } \\
\text { POPULATION }\end{array}$} \\
\hline Variable & Chategory & ap. & $\%$ & ap. & 9 & & $\mathrm{a}$ & & $\%$ \\
\hline Total & & 400 & 100.00 & 200 & 100 & .00 & & & 100.00 \\
\hline \multirow{4}{*}{$\begin{array}{l}\text { Do you } \\
\text { have an } \\
\text { unpleasant } \\
\text { experience } \\
\text { with the } \\
\text { police? }\end{array}$} & $\begin{array}{c}\text { Yes, } \\
\text { personally }\end{array}$ & 83 & 20.75 & 50 & 25 & & 3 & & 16.50 \\
\hline & $\begin{array}{c}\text { Yes, } \\
\text { somebody } \\
\text { from my } \\
\text { family }\end{array}$ & 59 & 14.75 & 43 & \multicolumn{2}{|c|}{21.50} & \multicolumn{2}{|c|}{16} & 8.00 \\
\hline & $\begin{array}{c}\text { Yes, some of } \\
\text { my } \\
\text { acquaintances }\end{array}$ & 116 & 29.00 & 54 & \multicolumn{2}{|c|}{27.00} & \multicolumn{2}{|c|}{62} & 31.00 \\
\hline & no & 142 & 35.50 & 53 & \multicolumn{2}{|c|}{26.50} & \multicolumn{2}{|c|}{89} & 44.50 \\
\hline \multicolumn{10}{|c|}{ Value of Hi-square } \\
\hline & \multicolumn{3}{|c|}{ THE SIGNIFICANCE TEST } & \multicolumn{6}{|c|}{ SYMETRIC MEASURES } \\
\hline & HI SQUARE & DF & SIG. & $\begin{array}{l}\text { CONTIG } \\
\text { N. COEFI }\end{array}$ & & $\begin{array}{r}\mathrm{PE} / \\
\mathrm{ON}\end{array}$ & & & $\begin{array}{l}\text { EARMA } \\
\mathrm{N} \\
\text { RRELAT }\end{array}$ \\
\hline & 25.516 & 3 & 0.000 & 0.245 & & & & & 0.219 \\
\hline
\end{tabular}

Table 3. Exceeding in police authority

\begin{tabular}{|c|c|c|c|c|c|c|c|}
\hline \multicolumn{8}{|c|}{ Absolute and relative frequencies } \\
\hline & & \multicolumn{2}{|c|}{ All } & \multicolumn{2}{|c|}{ THE ROMA } & \multicolumn{2}{|c|}{$\begin{array}{c}\text { OTHER } \\
\text { POPULATION }\end{array}$} \\
\hline Variable & Chategory & ap. & $\%$ & ap. & $\%$ & ap. & $\%$ \\
\hline Total & & 400 & 100.00 & 200 & 100.00 & 200 & 100.00 \\
\hline \multirow{4}{*}{$\begin{array}{l}\text { Do you } \\
\text { think that } \\
\text { the police } \\
\text { frequently } \\
\text { exceed } \\
\text { their } \\
\text { authority? }\end{array}$} & $\begin{array}{c}\text { Yes, } \\
\text { absolutely }\end{array}$ & 43 & 10.75 & 26 & 13.00 & 17 & 8.50 \\
\hline & Yes, probably & 167 & 41.75 & 97 & 48.50 & 70 & 35.00 \\
\hline & No, probably & 161 & 40.25 & 67 & 33.50 & 94 & 47.00 \\
\hline & No, absolutely & 29 & 7.25 & 10 & 5.00 & 19 & 9.50 \\
\hline
\end{tabular}




\begin{tabular}{|c|c|c|c|c|c|c|}
\hline \multicolumn{7}{|c|}{ Value of Hi-square } \\
\hline \multirow{2}{*|2}{ THE SIGNIFICANCE TEST } & \multicolumn{2}{|c|}{ SYMETRIC MEASURES } \\
\cline { 2 - 7 } & $\begin{array}{c}\text { HI } \\
\text { SQUARE }\end{array}$ & DF & SIGNIFICANCE & $\begin{array}{c}\text { CONTIGEN. } \\
\text { COEFF. }\end{array}$ & $\begin{array}{c}\text { PEARS- } \\
\text { ONS R }\end{array}$ & $\begin{array}{c}\text { SPEARM } \\
\text { AN } \\
\text { CORREL } \\
\text { AT. }\end{array}$ \\
\hline
\end{tabular}

Table 4. Information given by the police about the possibilities for citizens' complaints

\begin{tabular}{|c|c|c|c|c|c|c|c|c|}
\hline \multicolumn{9}{|c|}{ Absolute and relative frequencies } \\
\hline & & \multicolumn{3}{|c|}{ All } & \multicolumn{2}{|c|}{ THE ROMA } & \multicolumn{2}{|c|}{$\begin{array}{c}\text { OTHER } \\
\text { POPULATION }\end{array}$} \\
\hline Variable & \multicolumn{2}{|c|}{ Chategory } & ap. & $\%$ & ap. & $\%$ & ap. & $\%$ \\
\hline Total & & & 400 & 100.00 & 200 & 100. & 200 & 100.00 \\
\hline \multirow{4}{*}{$\begin{array}{l}\text { The police } \\
\text { sufficiently } \\
\text { informs } \\
\text { citizens } \\
\text { about } \\
\text { possibilities } \\
\text { for } \\
\text { complainin } \\
\text { g. }\end{array}$} & \multicolumn{2}{|c|}{$\begin{array}{c}\text { Yes, } \\
\text { absolutely }\end{array}$} & 10 & 2.50 & 7 & 3.5 & 3 & 1.50 \\
\hline & \multicolumn{2}{|c|}{$\begin{array}{c}\text { Yes, } \\
\text { probably }\end{array}$} & 153 & 38.25 & 60 & 30.00 & 93 & 46.50 \\
\hline & \multicolumn{2}{|c|}{$\begin{array}{c}\text { No, } \\
\text { probably }\end{array}$} & 176 & 44.00 & 96 & 48.00 & 80 & 40.00 \\
\hline & \multicolumn{2}{|c|}{$\begin{array}{c}\text { No, } \\
\text { absolutely }\end{array}$} & 61 & 15.25 & 37 & 18.50 & 24 & 12.00 \\
\hline \multicolumn{9}{|c|}{ Value of Hi-square } \\
\hline & \multicolumn{4}{|c|}{ THE SIGNIFICANCE TEST } & \multicolumn{4}{|c|}{ SYMETRIC MEASURES } \\
\hline & $\begin{array}{c}\text { HI } \\
\text { SQUARE }\end{array}$ & $\mathrm{DF}$ & \multicolumn{2}{|c|}{ SIGNIFICANCE } & \multicolumn{2}{|c|}{$\begin{array}{c}\text { CONTIGEN. } \\
\text { COEFF. }\end{array}$} & $\begin{array}{c}\text { PEARS- } \\
\text { ONS R }\end{array}$ & $\begin{array}{c}\text { SPEARM } \\
\text { AN } \\
\text { CORREL } \\
\text { AT. }\end{array}$ \\
\hline & 12.943 & 3 & \multicolumn{2}{|c|}{0.005} & \multicolumn{2}{|c|}{0.177} & -0.127 & -0.140 \\
\hline
\end{tabular}

Table 4 shows that 50 percent of the local population as a whole think that the police sufficiently informs the public about the possibilities for filing complaints while just one third of the Roma think that. In 66.5 percent of cases they think that the police probably or absolutely does not inform the public about the possibilities for filing complaints.

These indicators can be taken as relevant since the $x^{2}$ test is 12.943 , and with the third degree of freedom on the level of importance of 0.05 the marginal value of the test is 7.815 . 
Table 5. Advice given by the police about protection from crime

\begin{tabular}{|c|c|c|c|c|c|c|c|c|}
\hline \multicolumn{9}{|c|}{ Absolute and relative frequencies } \\
\hline \multirow[b]{2}{*}{ Variable } & \multirow[b]{2}{*}{ Chategory } & \multicolumn{2}{|c|}{ All } & \multicolumn{3}{|c|}{ THE ROMA } & \multicolumn{2}{|c|}{$\begin{array}{c}\text { OTHER } \\
\text { POPULATION }\end{array}$} \\
\hline & & ap. & $\%$ & ap. & 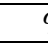 & & ap. & $\%$ \\
\hline Total & & 400 & 100.00 & 200 & 10 & & 200 & 100.00 \\
\hline \multirow{4}{*}{$\begin{array}{l}\text { The police } \\
\text { gives } \\
\text { sufficient } \\
\text { advice about } \\
\text { protection } \\
\text { from crime. }\end{array}$} & $\begin{array}{c}\text { Yes, } \\
\text { absolutely }\end{array}$ & 7 & 1.75 & 4 & \multicolumn{2}{|c|}{2.00} & 3 & 1.50 \\
\hline & $\begin{array}{c}\text { Yes, } \\
\text { probably }\end{array}$ & 207 & 51.75 & 94 & \multicolumn{2}{|c|}{47.00} & 113 & 56.50 \\
\hline & $\begin{array}{c}\text { No, } \\
\text { probably }\end{array}$ & 146 & 36.50 & 87 & \multicolumn{2}{|c|}{43.50} & 59 & 29.50 \\
\hline & $\begin{array}{c}\text { No, } \\
\text { absolutely }\end{array}$ & 40 & 10.00 & 15 & \multicolumn{2}{|c|}{7.50} & 25 & 12.50 \\
\hline \multicolumn{9}{|c|}{ Value of Hi-square } \\
\hline & \multicolumn{3}{|c|}{ THE SIGNIFICANCE TEST } & \multicolumn{5}{|c|}{ SYMETRIC MEASURES } \\
\hline & $\begin{array}{c}\text { HI } \\
\text { SQUARE }\end{array}$ & DF & $\begin{array}{l}\text { SIGNIFI } \\
\text { CANCE }\end{array}$ & $\begin{array}{r}\text { CONT } \\
. \mathrm{COI}\end{array}$ & & $\begin{array}{r}\mathrm{PE} \\
-\mathrm{C}\end{array}$ & & $\begin{array}{c}\text { SPEARMA } \\
\mathrm{N} \\
\text { CORRELA } \\
\mathrm{T} .\end{array}$ \\
\hline & 9.757 & 3 & 0.021 & 0.1 & & & & -0.051 \\
\hline
\end{tabular}

In table 5 the Roma estimates on the insufficient public knowledge about the protection from crime by the police are evident in 43.5 percent of (probably not) cases, and in 7.5 pecent of (absolutely not) cases, which is something more than a half of the Roma sample. In 56.5 percent of cases the local population estimates that it is possible that the police sufficiently informs the public about protection from crime.

The $x^{2}$ test value is 9.757 and it is larger than the marginal value on the third degree of freedom (7.815), which means that the indicators can be taken as relevant.

From the indicators in Table 6 it can be deduced that both the Roma and local population positively estimate the consistency of police officers. The Roma estimate this consistency as bad in 30 percent of cases or very bad in 10.5 percent of cases. The local population's estimates are lower - bad in 25.5 percent and very bad in 3.5 percent of cases.

The $x^{2}$ test variable is 10.768 and it is higher than the marginal value on the third degree of freedom (7.815), which means that the indicators are relevant, and not accidental. 
Table 6. Consistency of police officers

\begin{tabular}{|c|c|c|c|c|c|c|c|c|}
\hline \multicolumn{9}{|c|}{ Absolute and relative frequencies } \\
\hline \multirow[b]{2}{*}{ Variable } & \multirow[b]{2}{*}{$\begin{array}{c}\text { Chategor } \\
y\end{array}$} & \multicolumn{2}{|c|}{ All } & \multicolumn{3}{|c|}{ THE ROMA } & \multicolumn{2}{|c|}{$\begin{array}{c}\text { OTHER } \\
\text { POPULATION }\end{array}$} \\
\hline & & ap. & $\%$ & ap. & \multicolumn{2}{|c|}{$\%$} & ap. & $\%$ \\
\hline Total & & 400 & 100.00 & 200 & 100 & & 200 & 100.00 \\
\hline \multirow{4}{*}{$\begin{array}{l}\text { What is your } \\
\text { estimate of } \\
\text { the police } \\
\text { officers' } \\
\text { consistency? }\end{array}$} & $\begin{array}{l}\text { Very } \\
\text { good }\end{array}$ & 10 & 2.50 & 3 & \multicolumn{2}{|c|}{1.50} & 7 & 3.50 \\
\hline & Good & 251 & 62.75 & 116 & \multicolumn{2}{|c|}{58.00} & 135 & 67.50 \\
\hline & Bad & 111 & 27.75 & 60 & \multicolumn{2}{|c|}{30,00} & 51 & 25.50 \\
\hline & Very bad & 28 & 7.00 & 21 & \multicolumn{2}{|c|}{10.50} & 7 & 3.50 \\
\hline \multicolumn{9}{|c|}{ Value of Hi-square } \\
\hline & \multicolumn{3}{|c|}{ THE SIGNIFICANCE TEST } & \multicolumn{5}{|c|}{ SYMETRIC MEASURES } \\
\hline & $\begin{array}{c}\text { HI } \\
\text { SQUAR } \\
\text { E } \\
\end{array}$ & DF & $\begin{array}{l}\text { SIGNIF } \\
\text { ICANC } \\
\text { E }\end{array}$ & \multicolumn{2}{|c|}{$\begin{array}{c}\text { CONTIGEN. } \\
\text { COEFF. }\end{array}$} & \multicolumn{2}{|c|}{$\begin{array}{l}\text { PEARS- } \\
\text { ONS R }\end{array}$} & $\begin{array}{l}\text { SPEARMAN } \\
\text { CORRELAT. }\end{array}$ \\
\hline & 10.768 & 3 & 0.013 & \multicolumn{2}{|c|}{0.162} & & & -0.143 \\
\hline
\end{tabular}

\section{Conclusion}

It is not possible to confirm the results obtained from the hypothesis since there are differences between the examined groups. It can be concluded that the Roma and their family members have more personal unpleasant experiences with the police than the local population, they more often notice exceedings in police authority, they think they are insufficiently informed about the possibilities for compalaining or protection against crime, and consider the police inconsistent in their procedure.

These indicators can show institutional extremism. Since it is a question of subjective, and not objective estimates of police procedure, attention has to be payed before reaching a conclusion. It is sure that institutional extremism, i.e. the Roma's negative estimate of police officers' procedures, is not simply influenced by attitudes toward such procedures but also by some more factors which have not been studied here. It can be presupposed that it is a question of the Roma's negative experiences influence which is linked to their ethnic discrimination. Police officers which are seen by the Roma as having positive characteristics in certain aspects (e.g. consistency) do not show these characteristics in their procedures because they may show some of their own attitudes, like a negative attitude towards the Roma as an ethnic minority. 
The scientific and practical value of the results of this work provides the guidelines for the creation and implementation of the measures for the prevention of racism, intolerance and segregation, whereby a special role is played by the state bodies, primarily of the Istrian County and the local government.

Thinking about preventing institutional extremism the authors Hennesy (1993) and Bickham and Rossett (1993) say that each institution that takes into consideration minorities fights against the consciousness of a wider social community of the existance of different cultures and changes of population in communities. They emphasize that the existance of a so called "culturally competent" professional is a much more complex process than the sole acqusition of differences between different cultures. Single facts about the history and values of different minority groups are insufficient, and as a consequence many citizens see the police as not competent enough to act in a proper way in different environments. The conclusion is that some changes in the basic attitude towards minorities have to take place, and along with that ways of procedure have to be defined.

\section{Bibliography} Wadsworth.

Belknap, J. (1996). The Invisible Woman: Gender, Crime and Justice. Belmont. California:

Bickham, T. and Rossett, A. (1993). Diversity Training: Are We Doing the Right thing Right? The Police Chief, 43, 143-147.

Bowling, B. (1999). Violent Racism: Victimisation, Policing, and Social Context. Clarendon Studies in Criminology. Oxford: Oxford University Press.

Cajner Mraović, I. and Mraović, A. (2000). Extremistic violence: Some Basic Questions about the Fenomenology, Aetiology and Prevention of the Phenomenon? Police and Safety, 9, 174-186.

Franklin, K. (2000). Homophobia. In C.D. Bryant (Ed.) Encyclopedia of Criminology and Deviant Behiavior. Brunner Mazel/Routledge.

Hennessey, S. M. (1993). Achieving Cultural Competence. The Police Chief, 60,46-50.

Janofsky, M. (1997). Under Siege, Philadelphia's Criminal Justice System Suffers Another Blow. The New York Times. (April 10) str.14A.

Levin, J. (2002). The Violence of Hate: Confronting Racism, Anti-Semitism, and Other Forms of Bigotry. Allyn \& Bacon. Boston.

Ogawa, B.K. (1988). Couseling Victims of Sexual Assault. International Bulletin of Morita Therapy,1,19-25.

Ogawa, B.K. (1999). Colour of Justice: Culturally Sensitive Treatment of Minority Crime Victims. Allyn and Bacon. California.

Radetić-Paić, M. (2010): The Roma and Other Istrian Residents' Opinions about Some Aspects of the Level of Information of the Public by the Police in the Context of Education and Ethnic Discrimination. Metodički obzori. 5(1) 9, 19-30.

Schwendinger, J.R. and Schwendinger, N. (1983). Rape and Inequality. Beverly Hills. California: Sage. 
Šućur, Z. (2005). Poverty as a Part of the Sociocultural Identity of the Roma. In: M.Štambuk (Ed.), How do Croatian Rome Live (pp.271-315). Institute for Social Studies "Ivo Pilar," Zagreb.

The Croatian Government (2003). National Programme for the Roma

Westley, W. A. (2004). Violence and the Police. In: I. Kuvačić (Ed.), Introduction to Sociology (pp. 506-510). Golden Marketing-Tehnička knjiga, Zagreb.

Metodički obzori 7(2012)3

Izvorni znanstveni rad

UDK: 351.74:323.15(497.5-3Istra=214.58)

Received: 7. 12. 2010.

\title{
POSTUPANJE POLICIJE KAO MOGUĆI INDIKATOR INSTITUCIONALNOG EKSTREMIZMA
}

\author{
Mirjana Radetić - Paić, PhD \\ Department for the education of teachers and child-care teachers \\ University Juraj Dobrila in Pula \\ e-mail: mradeticpaic@ hotmail.com
}

Valter Opašić, univ.spec.oec., Ministry of Internal Affairs of the Republic of Croatian Head of Department of analytics reporting and public relations PU Istarske e-mail: vopasic@gmail.com

Ivan Kostešić, student, Department of Preschool and Primary Education e-mail: ivankontesic@gmail.com

\section{Sažetak}

Generalni cilj ovog rada je utvrditi da li postoje razlike u pojedinim aspektima postupanja policije prema Romima Istarske županije, Republika Hrvatska (N=200) u odnosu na domicilno stanovništvo istog područja $(\mathrm{N}=200)$. Pošlo se od pretpostavke da će Romi procjenjivati da je postupanje policije u pojedinim aspektima prema njima različito od postupanja prema domicilnom stanovništvu upravo zbog činjenice da su pripadnici jedne od manjinskih skupina, te da navedeno može biti indikator institucionalnog ekstremizma.

Rezultati pokazuju da Romi za razliku od domicilnog stanovništva imaju više osobnih neugodnih iskustava s policijom, kao i njihovi članovi obitelji, češće procjenjuju prekoračenja ovlasti policije, smatraju da su nedovoljno informirani o mogućnostima pritužbi građana i o savjetima o zaštiti od kriminala od strane policije, te procjenjuju lošiju dosljednost policije u svojem postupanju.

Znanstvena i aplikativna vrijednost rezultata ovog rada je da daje smjernice za kreiranje i implementaciju mjera za sprečavanje rasizma, netolerancije i segregacije Roma pri čemu je od posebne važnosti uloga državnih tijela, a prije svega Istarske županije i lokalne uprave.

Ključne riječi: institucionalni ekstremizam, policijsko postupanje, Romi 